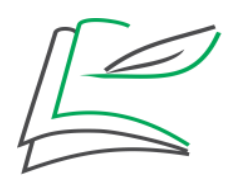

Entretextos

Entretextos 21(1): jan./jun. 2021

ISSN 1519-5392 UEL

DOI: $10.5433 / 1519-5392.2021 v 21$ n1.p.203

\title{
Dia Internacional da Mulher: aspectos ideológico- argumentativos no discurso do primeiro ano de mandato de Bolsonaro
}

\author{
International Women's Day: ideological and argumentative aspects of \\ Bolsonaro's speech in his first year at presidency
}

\begin{abstract}
Día Internacional de la Mujer: aspectos ideológico-argumentativos en el discurso del primer año de mandato de Bolsonaro
\end{abstract}

\author{
Michele Borges Chaves de Oliveira* \\ (D)https://orcid.org/0000-0003-3686-4671 \\ Isabel Cristina Cordeiro* \\ https://orcid.org/0000-0002-2391-9787
}

\begin{abstract}
RESUMO: O discurso é a materialização de posicionamentos do sujeito, construídos a partir de sua interpelação por ideologias distintas, dentro de um determinado momento sócio-histórico. 0 discurso político, especificamente, possibilita que o enunciador utilize uma diversidade de cenografias (MAINGUENEAU, 2005) para se dirigir a sua audiência. Portanto, através de revisão bibliográfica, este trabalho visa a analisar aspectos ideológico-argumentativos no discurso do presidente Jair Bolsonaro, na comemoração do Dia Internacional da Mulher em 2019, a fim de tecer considerações sobre a ideologia que rege seus posicionamentos e sobre o papel da seleção lexical em sua difusão. A análise indicou que a formação do presidente está enraizada em princípios cristãos, que produzem o efeito de sentido de que o papel fundamental da mulher é auxiliar o homem e edificar o lar. Nesse sentido, a seleção lexical se constitui como ferramenta que materializa posicionamentos oriundos dessa ideologia, rompendo, portanto, com qualquer suposta neutralidade do discurso. As palavras foram empregadas com sentido valorativo, a fim de enaltecer o papel da mulher como auxiliadora, tanto na sociedade quanto na família. A seleção lexical, como um todo, foi utilizada de maneira a buscar a diminuição do nível de formalidade e, consequentemente, aproximar o enunciador de sua audiência.
\end{abstract}

PALAVRAS-CHAVE: Ideologia. Discurso político. Dia Internacional da Mulher.

ABSTRACT: The discourse is the materialization of the individual's positioning, it is built from his interpellation by several ideologies in a certain socio-historical moment. The political discourse, in specific, enables the enunciator to use different scenographies (MAINGUENEAU, 2005) in order to talk to the audience. Therefore, through literature review, this paper aims to analyze argumentative and ideological aspects in Bolsonaro's speech in the celebration of 2019 International Women's Day, in order to discuss the ideology underlying his positionings, as well as the role of lexical selection in the spread of this ideology. The analysis showed that the

\footnotetext{
* Mestranda em Estudos da Linguagem, na Universidade Estadual de Londrina. E-mail: michele.bco@gmail.com

* Doutora em Estudos da Linguagem. Docente na Universidade Estadual de Londrina. E-mail: isabelcordeiro@uol.com.br
} 
president's positioning is based on Christian values which mean that a woman's fundamental role is to help the man and to raise their home. In this sense, lexical selection is settled as a tool that materialize positionings originated in this ideology, which break any neutrality assumed in the discourse. The words were used in a valuative sense, aiming to enhance the woman's role as a helper both in society and family. Lexical selection, as a whole, was used in order to decrease formality and, consequently, approach the speaker and his audience.

KEYWORDS: Ideology. Political discourse. International Women's Day.

RESUMEN: El discurso es la materialización de posiciones del sujeto, construido a partir de su interpelación por diferentes ideologías, en un momento sociohistórico dado. El discurso político, específicamente, permite que el hablante use una variedad de escenarios (MAINGUENEAU, 2005) para dirigirse a su audiencia. Así, mediante revisión bibliográfica, este trabajo tiene como objetivo analizar aspectos ideológicos y argumentativos en el discurso del presidente Bolsonaro, en la celebración del Día Internacional de la Mujer en 2019, con el fin de hacer consideraciones sobre la ideología que rige sus posiciones y sobre el papel de la selección léxica en su difusión. El análisis indicó que la formación del presidente se basa en principios cristianos, que producen el efecto de que el papel fundamental de las mujeres es ayudar a los hombres y edificar el hogar. En este sentido, la selección léxica es una herramienta que materializa posiciones derivadas de esta ideología, rompiendo con cualquier supuesta neutralidad del discurso. Las palabras se usaron de manera significativa para resaltar el papel de las mujeres como ayudantes, tanto en sociedad como en familia. La selección lexical, como un todo, se utilizó de manera que buscaba disminuir el nivel de formalidad y acercar al orador a su audiencia.

PALABRAS CLAVE: Ideología. Discurso político. Día Internacional de la Mujer.

\section{Introdução}

Pode-se dizer que o cenário político brasileiro, do final do século XX e do início do século XXI, tem sido um tanto quanto conturbado, pois se fizermos um recorte da linha do tempo e esmiuçarmos o período da redemocratização, cujo início remonta o ano de 1988, teremos, de um lado, um país que conseguiu alcançar, efetivamente, avanços políticos e econômicos. Por outro lado, entretanto, também iremos nos recordar de planos econômicos polêmicos e incontáveis escándalos políticos, que, em momentos distintos, culminaram em dois presidentes que sofreram processo de impeachment.

O caos político iniciado no ciclo eleitoral presidencial de 2014, com a apertada reeleição da então presidente Dilma Rousseff (PT) sobre Aécio Neves (PSDB), teve como desfecho, em 2018, a eleição do então deputado federal Jair Messias Bolsonaro à presidência da República.

Enquanto candidato, Bolsonaro - à época, afiliado ao PSL (Partido Social Liberal) - em virtude de declarações e atitudes polêmicas, foi acusado de homofobia, misoginia e racismo por alguns de seus adversários políticos, o que, no entanto, não freou sua 
eleição, em $2^{\circ}$ turno, com pouco mais de $55 \%$ dos votos válidos, sobre o adversário Fernando Haddad, candidato do Partido dos Trabalhadores (PT). Essa eleição, no contexto histórico, marcou o fim de 16 anos de hegemonia do PT - ou de um partido coligado - no cenário político brasileiro.

Como a relação de Bolsonaro com o eleitorado feminino foi bastante segmentada, culminando, durante a campanha, em movimentos virtuais denominados \#EleNão e \#EleSim, a proposta deste trabalho é debruçar-se sobre o discurso presidencial, em virtude da comemoração do Dia Internacional da Mulher, em seu primeiro ano de mandato: 2019.

\section{Fundamentação}

A Análise de Discurso, doravante $A D$, defende que o discurso é a materialização de posicionamentos do sujeito, construídos a partir de seu assujeitamento às distintas ideologias, em um determinado momento sócio-histórico, também, denominado de condições de produção. Nessa perspectiva, o sujeito não é um indivíduo corporificado; é, antes, uma voz, inconsciente, que só diz o que diz porque as condições de produção a que é submetido lhe permitem dizer. Isso significa que o sujeito, em $A D$, não é autônomo e, nessa relação de assujeitamento, língua e ideologia têm papel primordial. $O$ texto, que se constitui como a materialização da língua, é a ferramenta que alça o discurso, produzindo efeitos de sentido que resultam em algo, uma vez que a linguagem, verbal ou não, é sinônimo de interação. Tais efeitos de sentido tornam-se possíveis devido à interpelação do sujeito pela ideologia, que, materializada através da linguagem, torna-se inerente à construção dos sentidos.

A noção de ideologia, em $A D$, é um conceito central, que vai além de um conjunto de ideias. Nos estudos de Charaudeau e Maingueneau (2018), os autores afirmam que a noção deriva do trabalho de Althusser, representando "uma relação imaginária dos indivíduos com sua existência, que se concretiza materialmente em aparelhos e práticas. Segundo ele, a ideologia está ligada ao inconsciente pelo viés da interpelação dos indivíduos em sujeitos" (CHARAUDEAU; MAINGUENEAU, 2018, p. 267-268).Essa ligação ao inconsciente está fundamentada na psicanálise lacaniana - constituída como uma releitura da psicanálise freudiana - segundo a qual a linguística é o que dá veracidade ao inconsciente que, por sua vez, está contido na subjetividade. Sob essa perspectiva, o 
inconsciente é estruturado como linguagem e, portanto, não pode ser entendido como fantasia.

Outro conceito fundamental em $A D$ é o da interdiscursividade, ou memória discursiva. Orlandi (2001, p. 31) o classifica como:

[...] o saber discursivo que torna possível todo dizer e que retorna sob a forma do pré-construído, o já dito que está na base do dizível, sustentando cada tomada da palavra. O interdiscurso disponibiliza dizeres que afetam o modo como o sujeito significa em uma situação discursiva dada. [...] Todos esses sentidos já ditos por alguém, em algum lugar, em outros momentos, mesmo muito distantes, têm um efeito.

De acordo com essa definição, não há originalidade na enunciação: tudo o que está sendo dito no presente já foi dito em algum momento passado e será dito futuramente, sob condições de produção específicas. Esse conceito justifica-se pela interpelação a que o sujeito é submetido na perspectiva da AD.

A Linguística Textual, doravante LT, também propõe uma abordagem de interpretação no processo de construção do sentido, sendo o primeiro deles a noção de linguagem, que é vista "como forma de ação, ação sobre o mundo dotada de intencionalidade, veiculadora de ideologia, caracterizando-se, portanto, pela argumentatividade" (KOCH, 1987, p. 17). Nesse âmbito, há os critérios de construção do sentido, dentre os quais dois serão utilizados nesta análise: a intertextualidade e a intencionalidade.

De acordo com o critério de intertextualidade, "a produção/recepção de um dado texto depende do conhecimento de outros textos por parte dos interlocutores, ou seja, dos diversos tipos de relações que um texto mantém com outros textos" ( $\mathrm{KOCH}, 2009$, p. 42). A autora defende que a presença de um texto em outro é inevitável e, que a intertextualidade pode se manifestar de duas formas: explícita, quando a fonte do intertexto é informada, e implícita, quando não há "menção da fonte, com o objetivo quer de seguir-Ihe a orientação argumentativa, quer de colocá-lo em questão, para ridicularizálo ou argumentar em sentido contrário" (KOCH, 2009, p. 146). Como a intertextualidade é um fator discursivo, e não linguístico, esta depende do conhecimento prévio do receptor do texto para que a construção do sentido atinja seu objetivo total.

Koch $(2009$, p. 145) dá ao termo um sentido amplo e um restrito, por postular a 
existência de uma intertextualidade (ou polifonia) em sentido amplo, isto é, "constitutiva de todo e qualquer discurso" e de uma intertextualidade stricto sensu, "atestada, necessariamente, pela presença de um intertexto".

Para a autora, a intertextualidade é um poderoso recurso de argumentação: a intertextualidade explícita comporta um grau mais elevado de argumentatividade e a implícita, um grau menor, pois o intertexto pode se tornar ou não um argumento decisivo para convencer, persuadir e atrair o leitor. Portanto, a intertextualidade não é uma simples adição de textos, mas, sim, um trabalho de assimilação e de transformação de outros textos, com vista a determinados objetivos.

A noção de intertextualidade, da presença contínua de outros textos em determinado texto, leva-nos a refletir a respeito da individualidade e da coletividade em termos de criação, uma vez que todo texto nasce de uma criação coletiva: a voz do produtor do texto mescla-se ao coro de outras vozes que já trataram do mesmo assunto e com o qual está em acordo ou desacordo.

Quanto à intencionalidade, é encarada como um processo complexo de interpretação, pois cabe ao receptor do texto identificá-la.

[...] toda atividade de interpretação presente no cotidiano da linguagem fundamenta-se na suposição de que quem fala tem certas intenções, ao comunicar-se. Compreender uma enunciação é, nesse sentido, apreender essas intenções. A noção de intenção não tem, aqui, nenhuma realidade psicológica: ela é puramente lingüística, determinada pelo sentido do enunciado, portanto, linguisticamente constituída (KOCH, 1987, p. 24).

Percebe-se, portanto, que tanto em $A D$ como em $L T$, os elementos que proporcionam a construção do sentido, embora possam ser abordados separadamente, estabelecem, entre si, uma relação de interdependência. A diferença na perspectiva de abordagem entre as duas disciplinas atinge seu ponto máximo no critério de intencionalidade, que a LT considera como um evento puramente linguístico, e que a $A D$ desconsidera, em virtude da interpelação do sujeito pela ideologia. Ainda assim, é possível perceber pontos de convergência em suas perspectivas, em especial, no que tange ao conceito de intertextualidade e de interdiscursividade:

Charaudeau (1993d) vê no 'interdiscurso' um jogo de reenvios entre discursos que tiveram um suporte textual, mas de cuja configuração não 
se tem memória [...]. Por sua vez, o 'intertexto' seria um jogo de retomada de textos configurados e ligeiramente transformados" (CHARAUDEAU; MAINGUENEAU, 2018, p. 286).

Outro aspecto importante a respeito do discurso é que, entre as áreas que se dedicam a estudá-lo, é consenso que não há discurso neutro. A Semântica Argumentativa pondera que existem palavras com maior ou menor grau de argumentatividade, mas não trabalha com o conceito de palavras neutras; em LT, Koch (1987) defende que "a todo e qualquer discurso subjaz uma ideologia, na acepção mais ampla do termo. A neutralidade é apenas um mito: o discurso que se pretende 'neutro', ingênuo, contém também uma ideologia" (KOCH, 1987, p. 19) e, em AD, Orlandi (2001) afirma que "não há neutralidade nem mesmo no uso mais aparentemente cotidiano dos signos" (ORLANDI, 2001, p. 9).

Pode-se afirmar, portanto, que na escala da argumentatividade que subjaz a construção do discurso, a seleção lexical tem papel determinante. A escolha de determinados substantivos e verbos em detrimento de outros, a adjetivação, o uso de metáforas, a modalização e quaisquer outras estratégias de construção dizem muito a respeito da carga ideológico-argumentativa latente em um enunciado. Oliveira (2014) usa da citação de Andrade (2009) para ratificar que a seleção lexical tem a finalidade específica de transmitir a opinião do enunciador e aproximá-lo do receptor, a fim de proporcionar envolvimento entre ambos e, ao final do processo, transformar este em coenunciador daquele (ANDRADE, 2009 apud OLIVEIRA, 2014).

O discurso político, objeto de análise deste trabalho, traz em si uma particularidade: possibilita que o enunciador utilize uma diversidade de cenografias para se dirigir a sua audiência, conforme definição de Maingueneau (2005). O autor desenvolveu o conceito de cena de enunciação, constituído por três cenas distintas, denominadas de cena englobante, cena genérica e cenografia. A cena englobante seria o tipo de discurso, sua pragmática: neste trabalho, o discurso político. A cena genérica está associada ao gênero, à instituição discursiva, que aqui se manifesta como um discurso presidencial. Por fim, temos a cenografia, a qual não está submissa ao gênero, no entanto se constrói pelo próprio texto, e, nesta análise, constitui-se por uma abordagem comemorativa, em virtude do Dia Internacional da Mulher (MAINGUENEAU, 2005, p. 75). $O$ autor ainda afirma que,

O discurso político é $[\ldots]$ propício à diversidade das cenografias: um 
candidato poderá falar a seus eleitores como jovem executivo, como tecnocrata, como operário, como homem experiente etc. (MAINGUENEAU, 2005, p. 76).

\section{Metodologia}

Através de revisão bibliográfica, este artigo propõe-se a analisar o discurso do presidente Jair Messias Bolsonaro, em virtude da comemoração do Dia Internacional da Mulher no ano de 2019, a fim de tecer considerações sobre a ideologia que rege seus posicionamentos e sobre o papel da seleção lexical em sua difusão.

\section{Análise}

Na sequência, abaixo, aparece a transcrição do discurso presidencial, em virtude da comemoração do Dia Internacional da Mulher em 2019. As falas foram, literalmente, transcritas, no entanto, por tratar-se de um discurso oral, a paragrafação e pontuação foram determinadas pelas pesquisadoras.

Senhora Raquel Dodge, procuradora da República; minhas queridas ministras, Damares e Tereza Cristina; senhora vice-presidente da República, Paula Mourão; senhora Michelle Bolsonaro, presidente da República.

Em nome delas, eu quero dizer que amo todas vocês, mas sou apaixonado apenas por três mulheres: a dona Olinda, minha mãe, com 91 anos; a minha filha Laura, com 8 anos; e um dia mais nova do que eu, porque eu não vou dizer a idade, a senhora Michelle. Porque eu sou nascido em 21 de março; ela, em 22 de março.

A mensagem que eu quero transmitir a vocês: pra quem é cristão, o homem, sua costela, veio uma mulher, e a partir desse momento, pela graça de Deus, de vocês, vieram todos os homens. Está na Bíblia, também, que a mulher sábia edifica o lar (BÍBLIA, 2001).

Nós vivemos momentos de inflexão no Brasil; a própria eleição minha diz isso, respeitando todas aquelas que, porventura, votaram no outro candidato, ou tiveram outras opções.

O que eu vejo de mais sagrado numa pátria, numa nação, é a unicidade familiar. A família é a célula da sociedade, e uma família unida, uma família responsável, uma família com princípios e com valores edifica uma nação. E, em grande parte do nosso 
país, as famílias são dessa natureza. E devemos isso tudo, em grande parte, também, à garra, à vontade, à determinação e à fé das mulheres.

Nesse dia, que pra mim não é diferente dos demais, porque vocês estão em nossas vidas 24 horas por dia, eu quero dizer que vocês são quem, realmente, conduz o destino de uma nação. Não existe um homem que possa fazer uma política séria, se não tiver, não ao seu lado, mas junto de si, uma mulher com os mesmos princípios. Graças a Deus, eu tenho uma família consistente, e nós devemos buscar isso, pois, somente dessa maneira, nós podemos construir uma grande nação.

Então, e também, antes de concluir, dizer que, pela primeira vez na vida, o número de ministros e ministras está equilibrado em nosso governo. Nós temos vinte e dois ministérios; vinte homens e duas mulheres. Somente um pequeno detalhe: cada uma dessas mulheres que tão (sic) aqui equivalem (sic) por dez homens. A garra dessas duas transmite energia para os demais.

Assim sendo, para o bem do nosso Brasil, vocês contem com um aliado, com alguém que, de fato, respeita vocês (sic) e quer que vocês tenham paz e tranquilidade. No que depender de nós, vamos lutar e continuar lutando pra que cada vez mais vocês façam parte de nossas vidas. O futuro do Brasil, em grande parte, passa pela decisão de vocês.

Muito obrigado, mulheres do Brasil; sou apaixonado por todas vocês. Muito obrigado!

O objeto da análise deste artigo foi o discurso transcrito acima.

Retomando o conceito da cena de enunciação, proposto por Maingueneau (2005), temos o discurso político (cena englobante), materializado através do discurso presidencial (cena genérica), em um evento comemorativo (cenografia).

O discurso teve a duração exata de sete minutos e quarenta e nove segundos, mas o presidente apenas tomou a palavra após três minutos do início do evento, tendo sido precedido pela esposa, Michelle Bolsonaro, na apresentação das autoridades presentes, nas menções honrosas e na fala inicial.

Em posição de destaque perante a audiência, além do casal presidencial, estavam o vice-presidente, Hamilton Mourão; Paula Mourão, sua esposa; Damares Regina Alves, ministra da Mulher, da Família e dos Direitos Humanos; Tereza Cristina Corrêa da Costa 
Dias, ministra da Agricultura, Pecuária e Abastecimento; Raquel Dodge, Procuradora Geral da República, à época; e Janete Vaz, apresentada, pela primeira-dama, como líder do grupo Mulheres do Brasil. Michelle Bolsonaro também fez menção a Priscilla Roberta Gaspar de Oliveira, Secretária Nacional dos Direitos da Pessoa com Deficiência, e às senhoras agraciadas, Gisele Beck Figueiredo, Kamiru Kamaiurá e Carolina Angélica Moreira Sanchez Gomes. Segundo menção da própria primeira-dama, o público presente no discurso foi composto por funcionárias do Palácio do Planalto, do Palácio da Alvorada, da Granja do Torto e do Palácio do Jaburu. Durante todo o evento, houve tradução simultânea para a Língua Brasileira de Sinais.

Partiremos, deste momento em diante, para a análise efetiva do discurso do presidente.

Deve-se considerar que a expressividade de um enunciado se materializa através da escolha dos elementos lexicais, gramaticais e composicionais, o que revela sua importância na construção do sentido. O que concretiza a seleção lexical é o emprego de palavras de classes abertas, que proporcionam liberdade na escolha do léxico, tais como substantivo, adjetivo, verbo e advérbio. Especificamente sobre o adjetivo, Oliveira (2014, p. 182) afirma que

Uma função primordial do adjetivo consiste em tornar mais viva a manifestação de uma atitude emotiva diante da realidade; [...] 0 adjetivo, quando usado de forma elaborada, instaura uma relação ideológicoargumentativa que permite constatar e avaliar os traços reveladores de seu enunciador.

Durante sua fala, Bolsonaro usa, por vinte vezes, a adjetivação como recurso argumentativo, e todas elas denotam valor positivo, o que Neves (2000 apud OLIVEIRA 2014, p. 182) denomina de qualidade eufórica. Majoritariamente simples, a adjetivação tornou-se quaternária no trecho:

"Uma família unida, uma famíliaresponsável, uma família com princípios e com valores edifica uma nação." (linhas 15 e 16).

Nesse trecho, os adjetivos unida e responsável, bem como as locuções adjetivas com princípios e com valores têm como referencial o substantivo família. Além disso, pode-se perceber o paralelismo sintático constituído por adjunto adnominal / sujeito / 
adjunto adnominal em Uma família unida, uma família responsável, uma família com princípios. Os adjetivos, de modo especial, colaboram muito para a subjetividade da linguagem. Dotados de grande expressividade, estão intimamente relacionados com a intenção de quem produziu o texto. De acordo com Kerbrat-Orecchioni (1980, p.94), "Les adjectifs évaluatifs reflétent certaines particularités de la compétence culturelle et idéologique du sujet parlant."

Há palavras que carregam em si toda a responsabilidade do sentido do enunciado, e há instrumentos gramaticais encarregados de estabelecer a ligação entre as ideias. Segundo Lapa (1991), as palavras reais (também chamadas de lexemas) são o substantivo, o adjetivo, o verbo e, por vezes, o advérbio, o numeral e o pronome, conforme o papel que despenham no discurso.

A seleção lexical é o valor estilístico do emprego de alternativas lexicais em um texto; a escolha das palavras pode manifestar posicionamento, sentimento, emoção, pois, por trás da seleção lexical, há a intencionalidade do produtor e o uso de adjetivos é uma das formas de manifestar suas intenções.

Os operadores argumentativos ocupam lugar de destaque no discurso. Oliveira (2014, p. 192) postula que, "No âmbito da Semântica Argumentativa, os operadores argumentativos são elementos da gramática que, ligados a determinados enunciados, encaminham o leitor a uma dada conclusão, intimamente ligada às condições de uso". No discurso em questão, os operadores argumentativos mais utilizados pertencem à classe prototípica: conjunções, advérbios (oulocuções adverbiais) e pronomes. No entanto, para os propósitos desta análise, serão destacados apenas os operadores argumentativos empregados na sentença transcrita a seguir:

"Assim sendo, para o bem do nosso Brasil, vocês contem com um aliado, com alguém que, de fato, respeita vocês e quer que vocês tenham paz e tranquilidade." (linhas 30 e 31).

Nessa sentença, a locução conjuntiva Assim sendo funciona como um operador argumentativo que produz efeito de conclusão e, portanto, indica que o discurso está se encaminhando para o fim. O pronome pessoal nosso indica afetividade, e a locução

\footnotetext{
1 "Os adjetivos avaliativos refletem certas particularidades da competência cultural e ideológica do sujeito falante" (tradução nossa).
} 
adverbial de afirmação de fato adquire forte carga semântica, pois produz o efeito de que, não interessa o que seja dito, nem a polêmica em torno do assunto, a verdade é que o presidente se importa com as mulheres e busca o seu bem-estar. A repetição do pronome pessoal você pode, inicialmente, ser interpretada apenas como marca de oralidade, porém, intensifica o efeito de sentido de que o presidente se importa com as mulheres, constituindo-se, portanto, como um recurso argumentativo. Nesta sentença, também é possível evocar, a partir da seleção lexical, o conceito de cena de enunciação de Maingueneau (2005), para sintetizar o tema central do discurso: não importa o que a mídia ou a oposição divulgue, a mulher brasileira tem um presidente que se importa com ela.

A acumulação é outro recurso presente no discurso. Oliveira (2014, p. 185) menciona que "A acumulação é uma figura de caráter intensificador, a utilização de elementos, semântica e sintaticamente, interligados mobiliza, na mente do enunciatário, efeitos nitidamente persuasivos". Esse recurso foi utilizado em dois trechos:

"O que eu vejo de mais sagrado numa pátria, numa nação, é a unicidade familiar." (linha 14).

"E devemos isso tudo, em grande parte, também, à garra, à vontade, à determinação e à fé das mulheres." (linhas 17 e 18).

No primeiro trecho, há intensificação do valor afetivo do país, através da formação de duas locuções, constituídas pela contração de preposição e artigo indefinido, junto a um substantivo abstrato; no segundo trecho, intensificam-se atributos valorativos do caráter da mulher.

As marcas de oralidade, embora limitadas, devido à natureza formal do discurso, também se fazem presentes. Em dois momentos distintos, a forma oral pra, que substitui a norma padrão da preposição para, proporciona um efeito de informalidade e, por conseguinte, de aproximação com a audiência:

"[...] pra quem é cristão, o homem, sua costela, veio uma mulher, [...]" (linhas 8 e 9).

"Nesse dia, que pra mim não é diferente dos demais, [...]" (linha 18).

No último trecho, a expressão Nesse dia, que substitui a norma padrão Neste dia, 
é outra marca de oralidade que proporciona aproximação da audiência.

Analisemos outro trecho:

"Nós vivemos momentos de inflexão no Brasil; a própria eleição minha diz isso, [...]" (linha 11).

A ordem inversa do pronome possessivo na construção "a própria eleição minha", ao invés de minha própria eleição, enfatiza a primeira pessoa do discurso e também proporciona efeito de aproximação da audiência.

Sobre a classe morfológica dos artigos, Oliveira (2014, p. 191) menciona que "A presença (ou ausência) do artigo é determinada pela situação discursiva, pela intencionalidade do enunciador, isto é, a forma como ele deseja transmitir o conteúdo de seu texto". Nesta análise, o artigo definido, além de ser prototipicamente empregado, também indica marcas de oralidade e, portanto, traz tom de informalidade aos trechos em que é empregado:

"[... ] mas sou apaixonado apenas por três mulheres: a dona Olinda, minha mãe, com 91 anos; a minha filha Laura, com 8 anos; [...]" (linhas 4 a 6). "Nós vivemos momentos de inflexão no Brasil; a própria eleição minha diz isso, [...]" (linha 11).

Em momentos distintos de sua fala, o presidente deixa transparecer a formação cristã que $o$ interpela, pois menciona o trecho bíblico sobre a criação da mulher a partir da costela do homem, relatado, na Bíblia, no livro de Gênesis, enfatizando, com isso, a concepção Criacionista de sua crença, em detrimento da Evolucionista. Bolsonaro também se refere ao livro bíblico de Provérbios- capítulo 14, versículo 1 -, a fim de explicitar sua crença a respeito da importância da sabedoria feminina dentro da família, mencionando que

"Está na Bíblia, também, que a mulher sábia edifica o lar" (linha 10).

A seleção lexical, materializada através de adjetivos como cristão e sagrado, do substantivo fé, e de expressões como pela graça de Deus e graças a Deus ratificam essa crença. Um aspecto ideológico-argumentativo importante, neste ponto, é o fato de que o presidente idealiza a mulher a partir de uma visão bíblica, segundo o qual ela foi criada para auxiliar o homem: visão impopular e considerada machista por segmentos da 
sociedade contemporânea.

Nesta análise, entretanto, as interpretações machistas perdem forças, se confrontadas com outro aspecto ideológico-argumentativo, que é a importância atribuída pelo presidente ao papel da esposa, externada no trecho

"Não existe um homem que possa fazer uma política séria, se não tiver, não ao seu lado, mas junto de si, uma mulher com os mesmos princípios." (linhas 21 e 22).

A expressão não ao seu lado, mas junto de si transmite uma forte carga semântica, indicativa de que a sintonia de pensamento deve ser total entre marido e esposa, se o que se busca é uma vida política séria. $O$ posicionamento da primeira-dama, à parte de seu engajamento social, revela compreensão da força da defesa desses princípios, já que, em eventos públicos, ela se apresenta sorridente, acessível e adequada, no sentido de demonstrar saber o papel que lhe é atribuído.

É razoável afirmar que a valorização da esposa favorece a consolidação da imagem de Bolsonaro perante a opinião pública, em especial, no que diz respeito à valorização da mulher. No discurso analisado, a primeira-dama foi a primeira a se pronunciar; evento que pode ser considerado comum, se considerada a natureza do objeto desta análise. Bolsonaro, por sua vez, procurou demonstrar devoção, chegando a transparecer euforia quando se referiu à esposa, no início de sua fala. Essa preocupação em lhe dar voz já havia ocorrido, como em sua primeira manifestação pública na condição de presidente eleito, quando ofereceu a Michelle a opção de se pronunciar e, no dia da posse, quando ela discursou primeiro, na Língua Brasileira de Sinais.

O numeral, lugar retórico de quantidade, foi um recurso pouco explorado no discurso presidencial, tendo sido utilizado em apenas dois momentos: quando Bolsonaro mencionou a diferença de um dia no mês entre sua data de aniversário e a da esposa, e quando mencionou que, pela primeira vez, havia equilíbrio no número de ministros e ministras - vinte homens e duas mulheres - em um total de vinte e dois ministérios. Segundo ele, o equilíbrio estaria no fato de que cada uma das duas ministras equivale a dez homens.

À luz da Linguística Textual, essa consideração estabelece intertextualidade implícita com a reação da opinião pública a um discurso do então presidente Michel 
Temer, realizado em 2017, também em virtude da celebração do Dia Internacional da Mulher. Nessa perspectiva, percebe-se a intencionalidade de Bolsonaro em criticar, de forma velada, o episódio envolvendo Temer. O receptor da mensagem, entretanto, só consegue estabelecer um diálogo entre os fatos, se tiver conhecimento do evento de 2017.

Sob a perspectiva da Análise de Discurso, o conceito de interdiscursividade também pode ser evocado neste ponto, em virtude da repercussão do discurso de Temer. Para tanto, é necessário compreender as condições de produção: em 2017, o expresidente foi criticado pela imprensa, nacional e internacional, por realizar um discurso considerado machista, ao celebrar o Dia Internacional da Mulher. No exterior, entre outros órgãos de imprensa, o jornal britânico The Telegraph, sob a assinatura de James Rothwell, criticou o fato de Temer ter assumido o governo com 28 ministérios, compostos unicamente por ministros, dos quais dois foram substituídos por mulheres apenas após protestos (ROTHWELL, 2017).

A interdiscursividade estabelecida entre o discurso dos dois presidentes explicita a importância das condições de produção na construção do sentido, que vão além da seleção lexical empregada em cada discurso: temos dois enunciadores, ocupando o mesmo cargo (presidente da República), no mesmo ato comemorativo (celebração do Dia Internacional da Mulher), duas situações semelhantes (ministérios com apenas duas mulheres), mas reações públicas distintas, resultantes de efeitos de sentido originados a partir de posicionamentos anteriores: Temer, embora reeleito como vice-presidente de Dilma Rousseff em 2014, articulou o rompimento entre seu partido (PMDB) e o dela (PT), em março de 2016 (PASSARINHO; CALGARO, 2016). Em maio do mesmo ano, ao assumir a presidência, transformou-se em persona non grata para parte da opinião pública, em especial, para os defensores de sua ex-aliada, os quais o chamaram de golpista. Bolsonaro, por sua vez, foi chamado de homofóbico, misógino e racista, devido a atitudes e declarações polêmicas, durante o período de campanha e antes, quando ainda era parlamentar; no entanto, apesar das controvérsias, a parcela da população que o elegeu parecia considerá-lo uma espécie de salvador da pátria, modelo de homem honesto, incorruptível, diferente do político convencional (PMDB..., 2016).

A trajetória ascendente de Bolsonaro, que contrasta com a trajetória descendente de Temer, na ocasião de seus respectivos discursos comemorativos, representa como o 
momento sócio-histórico favoreceu aquele e desfavoreceu este, ainda que em situações semelhantes. O momento sócio-histórico, portanto, foi imprescindível para que, no discurso de Bolsonaro, a opinião pública não desse grande importânciaà declaração de que havia equilíbrio em um governo de vinte e dois ministérios, que contava com apenas duas ministras.

\section{Conclusão}

A análise do primeiro discurso de Jair Messias Bolsonaro como presidente da República, na comemoração do Dia Internacional da Mulher, revelou que sua formação está enraizada em princípios cristãos, o que produz o efeito de sentido de que o papel fundamental da mulher é auxiliar o homem e edificar o lar. Nesse sentido, a seleção lexical, em especial o emprego de palavras de classes abertas, como substantivos, adjetivos, advérbios e verbos, constitui-se como a ferramenta que materializa os posicionamentos oriundos dessa ideologia, rompendo, dessa forma, com qualquer suposta neutralidade do discurso. As palavras foram empregadas com sentido valorativo, servindo ao propósito de enaltecer o papel da mulher como auxiliadora, tanto na sociedade quanto na família. Os adjetivos merecem destaque especial, pois foram, unanimemente, empregados na atribuição de características positivas, revelando grande força persuasiva no discurso. A seleção lexical, como um todo, foi utilizada de maneira a buscar a diminuição do nível de formalidade e, consequentemente, aproximar o enunciador de sua audiência.

$\mathrm{Na}$ análise, também é possível estabelecer um diálogo entre o discurso de Bolsonaro e o discurso do ex-presidente Michel Temer, realizado em virtude da celebração do Dia Internacional da Mulher, em 2017.

À luz da Linguística Textual, esse diálogo se estabelece sobre a intertextualidade e a intencionalidade, critérios da construção do sentido. Sob a perspectiva da Análise de Discurso, ele se fundamenta sobre o critério de interdiscursividade, explicitando como o momento sócio-histórico pode interferir nos efeitos de sentido, mesmo que os dois presidentes se encontrassem em condições de produção aparentemente semelhantes.

Finalmente, sob a perspectiva da cena de enunciação, proposta por Maingueneau (2005), pode-se afirmar que Bolsonaro falou à audiência como homem que valoriza a esposa, que, verdadeiramente, se importa com as mulheres do Brasil e que procura seu 
bem-estar, a despeito de qualquer informação contrária que possa vir a ser divulgada.

\section{Referências}

BÍBLIA. Português. Bíblia sagrada. Versão Almeida. Barueri: Sociedade Bíblica do Brasil, 2001. CHARAUDEAU, Patrick; MAINGUENEAU, Dominique. Dicionário de análise do discurso. 3. ed. São Paulo: Contexto, 2018.

KERBRAT-ORECCHIONI, Catherine. L'Enonciation: de la subjectivité dans le langage. Paris: Armand Colin, 1980.

KOCH, Ingedore Grunfeld Villaça. Argumentação e linguagem. 2. ed. São Paulo: Cortez, 1987.

$\mathrm{KOCH}$, Ingedore Grunfeld Villaça. Introdução à linguística textual: trajetória e grandes temas. 2. ed. São Paulo: Martins Fontes, 2009.

LAPA, Manoel Rodrigues. Estilística da língua portuguesa. São Paulo: Martins Fontes, 1991.

MAINGUENEAU, Dominique. Ethos, cenografia, incorporação. In: AMOSSY, Ruth. (org.). Imagens de si no discurso: a construção do ethos. São Paulo: Contexto: 2005. p. 69-92.

OLIVEIRA, Esther Gomes. Aspectos ideológico-argumentativos em um conto de Judith Grossmann. In: OLIVEIRA, Esther Gomes de; SILVA, Suzete. (org.). Semântica e estilística: dimensões atuais do significado e do estilo. Homenagem a Nilce Sant'Anna Martins. Campinas, SP: Pontes Editores, 2014. p. 177-197.

ORLANDI, Eni P. Análise de discurso: princípios \& procedimentos. São Paulo: Pontes Editores, 2001.

PASSARINHO, Nathalia; CALGARO, Fernanda. Por aclamação, PMDB oficializa rompimento com governo Dilma. G1, Brasília, 29 mar. 2016. Disponível em:

http://g1.globo.com/politica/noticia/2016/03/por-aclamacao-pmdb-oficializa-rompimento-comgoverno-dilma.html. Acesso em: 25 jan. 2020.

PMDB rompe com o Governo Dilma. El País, São Paulo, 30 mar. 2016. Disponível em: https://brasil.elpais.com/brasil/2016/03/29/politica/1459271009_272077.html. Acesso em: 25 jan. 2020.

ROTHWELL, James. Brazilian president Michel Temer attacked for praising housekeeping skills in International Women's Day speech. The Telegraph, [s. l.], 9 mar. 2017. Disponível em: https://www.telegraph.co.uk/news/2017/03/09/brazilian-president-michel-temer-attackedpraising-housekeeping/. Acesso em: 25 jan. 2020. 
Submetido em: 03 ago. 2020. Aceito em: 14 out. 2020. 